Arab Univ. J. Agric. Sci., Ain Shams Univ., Cairo, 13(2), 285-296, 2005

\title{
UNTRADITIONAL METHODS OF P-APPLICATION FOR RAISING ITS EFFICIENCY ON SANDY SOIL
}

[17]

\author{
Nassar $^{1}$, K.E.M.; M.M. El-Shouny ${ }^{1}$ and S.F. El-Fiki ${ }^{1}$
}

\begin{abstract}
Soils of Egypt characterize with raising $\mathrm{pH}$ values, $\mathrm{CaCO}_{3}$ content, clay and $\mathrm{Fe}$ \& Al oxides. These factors contribute, to a large extent, in P-fixation in soil and its transformation into unavailable forms. This reflect, in turn, on plant growth and the resultant crop. So, the main target of this investigation is raising the use efficiency of P-fertilization, decreasing P-fixation, increasing its availability in soil and promoting its uptake by plant through testing new methods for P-application compared with the traditional one ( $\mathrm{P}$-application before sowing). Therefore, two field experiments were designed in sandy soils during the two winter seasons 2002/2003 and 2003/2004 at South Tahrir Res. Station, Ali Moubark village, El-Bustan region, Behira governorate under drip irrigation system. For the two experiments, $\mathrm{P}$ was applied as soil or seed coating. Soil application treatments were added at a rate of $30 \mathrm{~kg} \mathrm{P}_{2} \mathrm{O}_{5} / \mathrm{fed}$., once before sowing, twice: before sowing and during the vegetative growth stages or in three portions, before sowing and during the vegetative and flowering growth stages. In seed coating method, seed were coated before sowing with $\mathrm{P}$ at rates of $0.1,0.2$ and $0.3 \mathrm{~kg} \mathrm{P}_{2} \mathrm{O}_{5} / \mathrm{kg}$ seed. Data obtained revealed that the treatments of P-soil application generally surpassed the P-seed coating ones. In this respect, P-soil application in three portions (at sowing and during the vegetative and flowering growth stages) gave the highest increments in seed, straw and seed protein yields as well as macro- and micronutrients contents in both seed and straw compared with the traditional method of soil P-application. Moreover, seed coated with $0.2 \mathrm{~kg} \mathrm{P}_{2} \mathrm{O}_{5} / \mathrm{kg}$ seeds attained the highest increases in all abovementioned yield components and nutritive contents among the treatments of seed coating method, whereas, coating of seeds with $0.3 \mathrm{~kg} \mathrm{P}_{2} \mathrm{O}_{5} / \mathrm{kg}$ seeds caused the least ones. Therefore, it can be concluded that the addition of $\mathrm{P}$ to sandy soil at a rate of $30 \mathrm{~kg} \mathrm{P}_{2} \mathrm{O}_{5} / \mathrm{fed}$., in three portions, i.e. at sowing and during the vegetative and flowering growth stages reduce $\mathrm{P}$ fixation by soil factors, increase its availability, promote its uptake by plant, achieve the highest productivity of faba bean seed, straw and seed protein yields and improve the nutritive contents of both seeds and straw.
\end{abstract}

Key words: P-fertilization, Seed coating, Faba bean, Sandy soil.

1- Soils, Water and Environment Research Institute; Agricultural Research Center, Giza, Egypt

(Received September 15, 2004)

(Accepted October 25, 2004) 


\section{INTRODUCTION}

As faba bean takes the first place among the most important legumes raised in Egypt, back-up research has been focused on this particular crop to maximize its production through increasing the efficiency of fertilization.

Phosphatic fertilization is generally important for leguminous crops. This, in fact due to a fundamental role of $\mathrm{P}$ in a large number of enzymatic reactions depending on phosphorylation and in the synthesis of various organic compounds in the plant. For this reason, plant meristematic tissues take up much of $\mathrm{P}$ in the early stages of growth and become vigorous (Mohammad, 1998 and Nassar et al 2001). Moreover, $P$ has an enhancing impact on plant growth and the resultant crop through its importance as energy storage and transfer necessary for the metabolic processes. $\mathrm{P}$ also raises the activity of rhizobia and increases the number of branches and pods/ plant, consequently produces more sizeable organs (Omran et al 1999; Nassar \& Ismail, 1999; Rahmou, 2003 and Nassar et al 2004).

Numerous investigators tried to find out the best and suitable method of $\mathrm{P}$ fertilizer. This attention was related to the problems of $\mathrm{P}$ availability in most of the soils of Egypt where, P-availability is a very sensitive to $\mathrm{pH}$ value, $\mathrm{CaCO}_{3} \%$ and contents of both organic matter and $\mathrm{Fe} \&$ Al oxides. So, several investigations tried to raise the efficiency of P-fertilizer through its splitting into several doses or its application as seed coating before sowing. In this concern, Dawood \& Abou Salama (1994) and Rahmou (2003) found that $P$ splitting into two doses, at the sowing and first irrigation
(Mohayah irrigation) led to an increase of yield and its attributes. The highest values of seed protein were recorded when applying P-fertilizer in two splitted doses (at first irrigation and flowering stage). On the other hand, Ibrahim \& Shalaby (1994); Nassar (1997) and Nassar et al (2002) attributed the efficiency of seed coating method with the nutrients to their effect on the proliferation of roots through the soil. This leads the plant roots to absorb more nutrients and correct the suitable requirements of macro- and micronutrients for plant growth that reflect on the resultant crop.

Therefore, the aim of this work was to throw some light on the effect of P application either to the soil, in splitting doses, or as seed coating on the quantity and quality of faba bean grown on sandy soil.

\section{MATERIAL AND METHODS}

Two field experiments were carried out at South Tahrir Agric. Res. Station, Agric. Res. Center, Ali Moubark Village, El-Bustan region, Behira governorate during the two winter seasons (2002/2003 and 2003/2004). This study was performed as sake of comparing the effect of P-fertilization added either to the soil in splitting doses or as seed coating. Soil samples were taken, before sowing, from the surface layer $(0-30 \mathrm{~cm})$ for physical and chemical analyses according to Jackson (1973). Some soil physical and chemical characteristics are shown in Table (1).

Faba bean seeds, Gizablanka cultivar, were sown in rows on $9^{\text {th }}$ and $15^{\text {th }}$ November for the first and second seasons, respectively. The treatments were arranged in complete randomized blocks with four replicates. The plot area was 
Table 1. Some physiochemical characteristics and fertility status of the studied soils during 2002/2003 and 2003/2004 winter seasons.

I- Physiochemical characteristics

\begin{tabular}{|ccccccccccc|}
\hline \multirow{3}{*}{ Season } & \multicolumn{3}{c}{ Particle size distribution } & Soil & $\mathrm{pH}$ & E.C. & Available & O.M. & $\mathrm{CaCO}_{3}$ \\
\cline { 2 - 5 } & $\begin{array}{c}\text { Sand } \\
(\%)\end{array}$ & Silt & Clay & texture & $(1: 2.5)$ & $($ d.S/m) & water $(\%)$ & $(\%)$ & $(\%)$ \\
\hline $2002 / 2003$ & 91.15 & 5.74 & 3.11 & Sandy & 8.57 & 0.77 & 4.61 & 0.13 & 4.70 \\
$2003 / 2004$ & 89.84 & 6.23 & 3.93 & Sandy & 8.43 & 0.64 & 4.79 & 0.18 & 4.59 \\
\hline
\end{tabular}

II- Fertility status

\begin{tabular}{|cccccccc|}
\hline \multirow{2}{*}{ Season } & \multicolumn{7}{c|}{ Available nutrients (ppm) } \\
\cline { 2 - 8 } & \multicolumn{7}{c|}{ Macro- } \\
\cline { 2 - 8 } & $\mathrm{N}$ & $\mathrm{P}$ & $\mathrm{K}$ & $\mathrm{Fe}$ & $\mathrm{Zn}$ & $\mathrm{Mn}$ & $\mathrm{Cu}$ \\
\hline $2002 / 2003$ & 20.4 & 1.9 & 62.8 & 0.69 & 0.10 & 0.25 & 0.06 \\
$2003 / 2004$ & 22.1 & 2.2 & 71.9 & 0.85 & 0.15 & 0.32 & 0.09 \\
\hline
\end{tabular}

$10.5 \mathrm{~m}^{2}(3 \times 3.5 \mathrm{~m})$. Each replicate was divided into two parts. The first one was fertilized with $30 \mathrm{~kg} \mathrm{P}_{2} \mathrm{O}_{5} / \mathrm{fed}$. as monocalcium phosphate, at one dose (before sowing, tradional methed), two doses (at sowing and during the vegetative growth stage at 30 days old, respectively) and three equal doses (before sowing and during the vegetative and flowering growth stages at 30 and 50 days old, respectively). Whereas, the second part was $\mathrm{P}$ fertilized by seed coating method with monocalcium phosphate. Treatments of $P$ seed coating were carried out before planting at the rates of $0.1,0.2$ and $0.3 \mathrm{~kg}$ $\mathrm{P}_{2} \mathrm{O}_{5} / \mathrm{kg}$ seeds. A control treatment (with- out P) was also taken into consideration. The normal cultural practices needed for growing faba bean were done.

At harvesting on $9^{\text {th }}$ and $11^{\text {th }}$ April for the two seasons, respectively, seed, straw and whole faba bean yields were estimated. Some seed yield components, i.e. number of seeds/plant, seed weight (g/plant) and 100 seed weight (g) were also recorded. From each plot, samples of both seeds and straw were taken for determining NPK as well as Zn, Mn, Fe and $\mathrm{Cu}$ uptake according to Chapman and Pratt (1961) and data of their contents were expressed as ( $\mathrm{Kg} / \mathrm{fed}$.) for macronutrients and $(\mathrm{g} / \mathrm{fed})$ for micronutrients. 
Seed protein content was estimated by multiplying seed $\mathrm{N}$ content by a factor of 6.25 .

The obtained data for all treatments except control were statistically analyzed according to Gomez and Gomez (1984). L.S.D. test at 5\% level of significance was used for comparison between the means of different treatments.

\section{RESULTS AND DISCUSSION}

\section{I-Yield and yield components}

Data obtained in Table (2) indicate that application of P-fertilization under the investigated methods of application (splitting the soil application dose or seed coating methed) significantly increased both faba bean seed and straw yields and insignificantly enhanced the components of seed yield, i.e. number of seeds, seed weight/ plant and 100 seed weight except 100 seed weight for the second season. Respecting the $\mathrm{P}$ soil application, splitting P-fertilizer into three equal doses (at sowing and during the vegetative and flowering growth stages, respectively) gave the highest increments of all tested characteristics. Whereas, seed coating with $0.2 \mathrm{~kg} \mathrm{P}_{2} \mathrm{O}_{5} / \mathrm{kg}$ seeds was the best treatment for increasing the same parameters among the treatments of seed coating method. Generally, treatments of P-soil application surpassed the seed coating ones. In this concern, soil application of $30 \mathrm{~kg} \mathrm{P}_{2} \mathrm{O}_{5} / \mathrm{fed}$. at three equal doses had the superiority effect.

The enhancing impact of $\mathrm{P}$ fertilization on faba bean seed and straw yields may be due to that $P$ enables the plants to grow well, raises the efficiency of plants to photosynthesis, enhances the activity of rhizobia, enzymes and hor- mones and increases the number of branches and pods/ plant. Consequently, $\mathrm{P}$ produces more sizeable organs (Szirtes et al 1986). $P$ also has an enhancing impact on plant growth and biological yield through its importance as energy storage and transfer necessary for metabolic processes (Marschner, 1998). These results are in hormony with those attained by (Omran et al 1999; Nassar \& Ismail, 1999; Rahmou, 2003 and Nassar et al 2004). On the other hand, the positive effect of $P$ when its addition as seed coating on faba bean yield may be due to the increase of $\mathrm{P}$ concentration in the vicinity of plant roots and raising its availability in the soil solution as well as reducing $\mathrm{P}$ fixation by soil factors (Fontes \& Welcox, 1983 and Nassar et al 2001).

The superiority impact of $\mathrm{P}$ when its application in several portions may be attributed to one or more of the following:

1- Reducing P-fixation by soil factors.

2- Producing the plants with available $\mathrm{P}$ along with their different growth stages, consequently increasing the corresponding values of both seed and straw yields, Table (2). Similar findings were reported by Dawood and Abou Salama (1994) and Rahmou (2003).

\section{II- Macro-and micronutrients contents}

\section{1- Macronutrients content}

Data presented in Table (3) show that NPK uptake in seed, straw and whole faba bean plants and seed protein content significantly increased with $\mathrm{P}$ fertilization. The highest values of NPK 
$\mathrm{P}$ application in sandy soil

Arab Univ. J. Agric. Sci., 13(2), 2005 
Nassar; El-Shouny and El-Fiki

Arab Univ. J. Agric. Sci., 13(2), 2005 
uptake and seed protein content were attained by the soil application of $30 \mathrm{~kg}$ $\mathrm{P}_{2} \mathrm{O}_{5} /$ fed. in three splitted equal doses. For P seed coating method, data of Table (3) also cleared that NPK uptake by all abovementioned parameters gradually increased as raising the rate of applied $\mathrm{P}$ up to $0.2 \mathrm{~kg} \mathrm{P}_{2} \mathrm{O}_{5} / \mathrm{kg}$ seeds then it declined but all values still higher than the control treatment. In general, the soil application method surpassed the seed coating one in its impact on NPK uptake by faba bean seed, straw and whole plant and seed protein content for the two investigated seasons. Similar findings were also reported by Mahmoud et al (1991) on soybean and Rahmou (2003) on faba bean.

\section{2- Micronutrients content}

Data in Table (4) show the effect of $\mathrm{P}$ application under the two investigated methods on micronutrients uptake $(\mathrm{Fe}$, $\mathrm{Zn}, \mathrm{Mn}$ and $\mathrm{Cu}$ ) by seed, straw and whole faba bean plants. The obtained results clearly revealed that micronutrients uptake in all abovementioned parameters took trends similar to those attained with macronutrients.

The positive effect of $\mathrm{P}$ application on the contents of macro-and micronutrients in various organs of faba bean plants may be due to:

A- Enhancing the activity of rhizobia as well as increasing the nodule number, size and mass, which in turn increase $\mathrm{N}_{2^{-}}$ fixation by $\mathrm{N}_{2}$ fixing microorganisms (Nassar et al 2001).

B- The close relationship between K-uptake and ATP-ase activity which increases by $\mathrm{P}$ application (Marschner, 1998).

C- Contribution of macro-and micronutrients in vital plant processes such as protein and carbohydrate construction, cell division and expansion, proteins and nucleic acids synthesis as well as respiration and photosynthesis (Dwivedi and Chaubey, 1995).

D- Contribution of $\mathrm{P}$ and the determined micronutrients (Fe, $\mathrm{Mn}$, $\mathrm{Zn}$ and $\mathrm{Cu}$ ) in assimilation processes of organic and inorganic phosphatic compounds, i.e. phosphoproteins, phospholipids and phosphocarbohydrates (Nassar et al 2002).

E- Increasing the corresponding values of seed and straw yields, as indicated in Table (2).

The promoting impact of $\mathrm{P}$ when its addition as seed coating on NPK and micronutrients uptake could be attributed to increasing the proliferation of roots through the soil. This leads them to absorb more nutrients and correct the suitable requirements of macro- and micronutrients for plant growth. 
Nassar; El-Shouny and El-Fiki

Arab Univ. J. Agric. Sci., 13(2), 2005 
$\mathrm{P}$ application in sandy soil

Arab Univ. J. Agric. Sci., 13(2), 2005 


\section{REFERENCES}

Chapman, D.H. and P.F. Pratt (1961). Methods of Analysis for Soil, Plant and Water. pp 100-128. Division of Agric. Sci., Univ. of California, U.S.A.

Dawood, R.A. and A.M. Abou Salama (1994). Effect of rate and timing of phosphorus application on yield and quality of faba bean (Vicia faba L.). Assuit J. Agric. Sci 25(3): 15-29.

Dwivedi, K.N. and A.K. Chaubey (1995). Effect of N.P. and S on soil content, iodine value and lipoxygenase activity of linseed oil. J. Ind. Soc. Soil Sci. 43(1): 75.77 .

Fontes, P.C.R. and G.E. Welcox (1983). Establishing sorption isotherm to meet phosphorus requirement for tomato seedling growth.J. Plant Nutrition 6:863-876. Gomez, K.A. and A.A. Gomez (1984). Statistical Procedures for Agricultural Research. John Wiley and Sons. Inc., New York.

Ibrahim, M.E. and M.H. Shalaby (1994). Effect of some micronutrients and methods of their application on growth, yield and mineral composition of wheat. Annals Agric. Sci. Moshtohor, 32(3): 1371-1388.

Jackson, M.L. (1973). Soil Chemical Analysis. pp. 498-550. Prentice-Hall of Indian, Pricate Limited, New Delhi.

Mahmoud, S.M.; R.A. Dawood and K.A. Kheiralla (1991). Effect of inoculation with bradyrhizobia and phosphorus fertilization at various growth stages on field grown soybean. Assuit J. Agric. Sci. 22(5): 55-68.

Marschner, H. (1998). Mineral Nutrition in Higher Plants. pp. 229-299. Academic Press, Harcount Brace Jovanovisch Publisher, London.
Mohammed, E.E.A. (1998). Efficiency of Phosphorus Fertilization in Sandy Soils. pp. 76-85. M.Sc. Thesis, Al-Azhar Univ., Cairo, Egypt.

Nassar, K.E.M. (1997). Some Factors Affecting the Absorption of Micronutrients by Plant. pp. 25-36. Ph.D. Thesis, Fac. Agric., Menofiya Univ., Shebin ElKom, Egypt.

Nassar, K.E. and K.M. Ismail (1999). Effect of ascorbic acid and phosphorus application on lupin yield (Lupinus termis L.) grown on sandy soil. Egypt. J. Appl. Sci. 14(10): 357-368.

Nassar, K.E.; A.A. Rahmou and E.M.K. Behiry (2001). Effect of phosphorus fertilization on Egyptian clover. Minufiya J. Agric. Res. 26(6): 17231733.

Nassar, K.E.; A.O.Osman; M.H. ElKholy and Madiha M. Badran (2002). Effect of seed coating with some micronutrients on Faba bean (Vicia faba L.). Egypt. J. Soil Sci. 42(3): 363-381.

Nassar, K.E.M.; Madiha M. Badran; M.M. El-Shouny and A.O. Osman (2004). Response of two lentil cultivars to irrigation and phosphatic fertilization. Minufiya J. Agric. Res. 29(1): 321-332.

Omran, A.A.; M.H. El-Khouly and A. Kh. Ahmed (1999). Effect of phosphorus and boron spraying on cotton yield. Egypt. J. Appl. Sci. 14 (12): 393-402.

Osman, A.A.; M.H. El-Kholy and A.Kh. Ahmed (1999). Effect of phosphorus and boron spraying on cotton yield. Egypt. J. Appl. Sci. 14(12): 393-402.

Rahmou, A.A. (2003). The effect of rates and time of phosphorus application on the yield and quality of some faba bean cultivars (Vicia faba L.) grown on an alluvial soil. Minufiya J. Agric. Res. 28(3): 9891002. 
بحلة اتحاد الجامعات العربية للدراسات والبحوث الزراعية، جامعة عين شمس، القاهرة ، 13(2)، 285-296، 2005

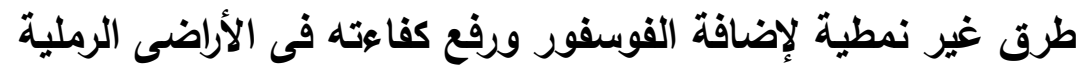

[17]

\section{كرم السيد محمد نصار 1 - مطاوع مطاوع الشونى 1 - سمير فتوح الفقى 1 1- معهز بحوث الأراضي والمياه والبيئة ـ مركز البحوث الزراعية ـ الجيزة ـ مصر}

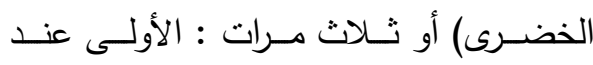

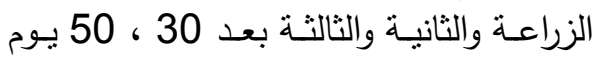
من الزراعة (مرحلتى النمو الخضرى والزهرى) أما الأسلوب الآخر المختبر لإضـافة الفوسفور

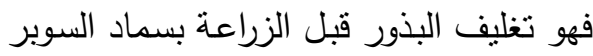

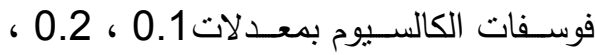

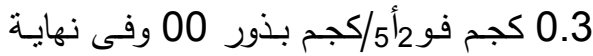
موسمى الزراعة حللت النتائج احصائيا لتقييم

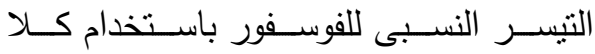

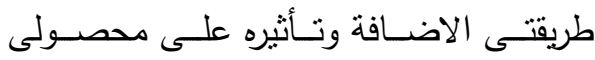

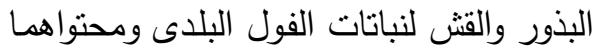

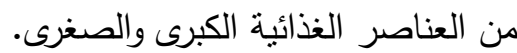

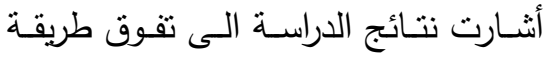

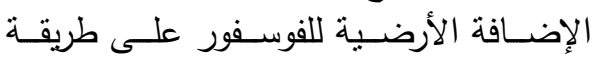

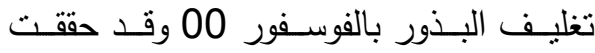

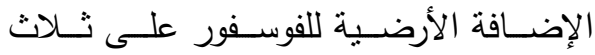

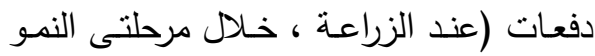

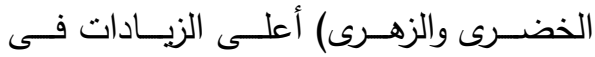

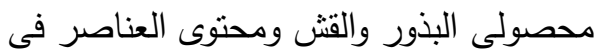
كل منهما وأيضا محتوى البذور ولفن من البذوى البروتين

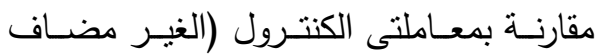

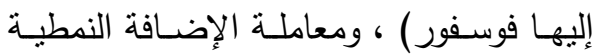
للفوسفور (إضافته كدفعة واحدة عند الزراعة) 00 فضلا عن أن معاملة تغليف بذور الفول
تتميـز الأراضـى الهصـرية باتجــاه رقـم

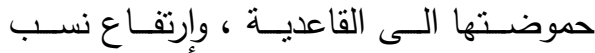

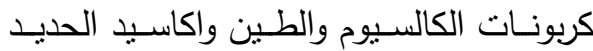

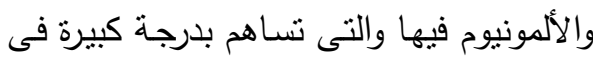

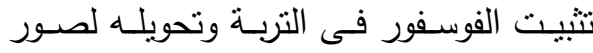

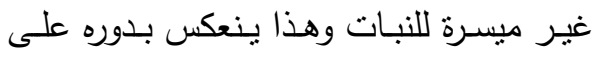

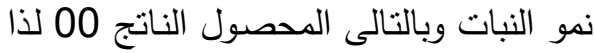
فإن رفع كفاءة استخدام الفوسفور بتقليل تثبيته

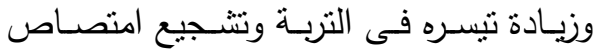

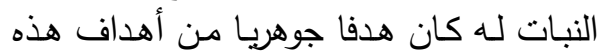

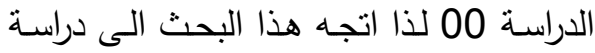
طريقتين جديدتين لإضـافة الفوسفور مقارنـة الإنة بالأسلوب التقليدى لإضـافته (إضـافته كجرعة لإضـا

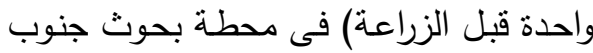

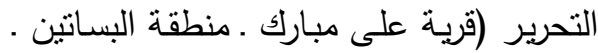

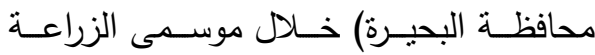

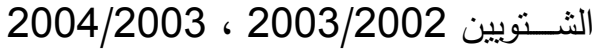
حيـث أضـيف الفوسـور فـى كـلا التجـربنتين بأسلوبين : الإضافة الأرضية فى صورة الفي سماد السـوبر فوسـفات الكالسـيوم الأحـادى (15)

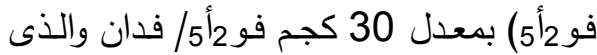
أضيف إما مرة واحدة عند الزراعة (الطريقة

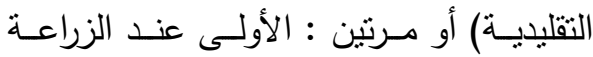
والثانية بعد 30 يوم من الزراعة (مرحلة النمو الأري 
ومن ثم يمكن التوصية بإضافة الفوسفور للأراضى الرملية بمعدل 30 كجم فو 2أك/فدان لأنان

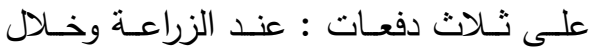
مرحلتى النمو الخضرى والزهرى بهدف تقليل

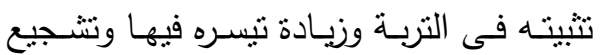

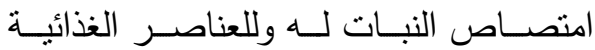

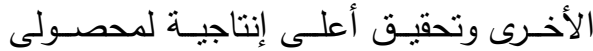
البذور والقش لدحصول الفول البلدى. الناجي.
بمعدل 0.2 كجم فـوأم / كجم بـذور قــ

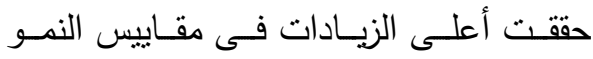

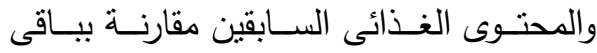

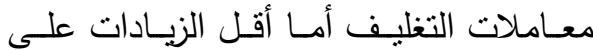
الإطلاق فقد سجلت عند تغليف البذور بمعدل 0.3 كجم فو أك/كجم بذور .
تحكيم: ا.د محمد أحمد مصطفى

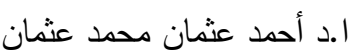

